\title{
The Communication Strategies Used in English Classroom Presentation by the English Education Students of UNIMUDA Sorong
}

\author{
Nurteteng \\ teteng.syaid72@gmail.com
}

\section{Education University of Muhammadiyah Sorong}

\begin{abstract}
The study attempts to analyze the types of communication strategies used in English classroom presentation by the English education students of UNIMUDA Sorong and the reasons why they used the strategy. The study took place at UNIMUDA Sorong in TEFL class where 30 students were participated and observed during their presentation activity in this subject. The study employed descriptive method, where the data obtained through open interviewed and video recording. The result showed that from twelve features of communication strategies, there are six of them that the students used during presentation. They are appoximation, circumlocation, examplification, word coinages, code switching and use fo fillers. Circumlocation was used because the students wanted to make direct contact to the students in order to make the successful teaching and learning process. Examplification was used because it can reflect the meaning of the concept. Word coinages was used because they might forget the appropriate words/term. Code switching was used because they felt more comfortable in case she combined between Bahasa Indonesia and the English language. Use of fillers was used because the strategy was very significant particularly second or foreign language speaker. The most frequently communication strategy that the students used is use of fillers.
\end{abstract}

Key words: Communication, Strategies, Classroom, Presentation.

\section{INTRODUCTION}

Language as a means of communication holds an important role in human interaction and could be categorized into spoken and written language. In human life interaction or communication, spoken language holds an important role, because spoken language can express feelings, intensions and emotions directly in human interaction or in building good relationship with others. However, some people find some difficulties in their interaction with others. In interaction, people do not only use their first language, but also foreign language or second language, this is mostly English. Nowadays, foreign language or second language becomes very important in this globalization era. That is why everyone is demanded to acquire it.

Ellis (1997) said that communication strategies are ways to make the conversation go on because every learner in a second language actually has a problem in saying what they want to say because of their inadequate knowledge. Communication strategies are used by the speakers when they face some difficulties due to the fact that their communication ends outrun their communication means or when confronted with misunderstanding by the listener (Corder, 1983; Tarone, 1983). According to Littlewood (1991), the students are sometimes ashamed of their oral 
performances which make them to choose to be silent or avoid communicating instead of making mistakes or errors.

Based on the brief theories and definitions on Communication Strategies above, the researcher attempts to relate those strategies with teaching and learning process in which English is used. As we have seen, Graduate Program, State University of Makassar, one of the ways to observe students in using English during individual or group presentation. In this case, the researcher is able to observe the kinds of communication strategies employed during presentation which is expected to generate mutual understanding between presenter and the participants.

There are basically only two main categories of communication strategies: reduction strategies and achievement strategies. The former is adopted by the learner who attempts to do away with a problem. They involve the learners giving up part of his/her original communicative goal and achievement strategies. The latter is taken by the learner when he/she decides to keep the original communicative goal but compensate for insufficient means, or makes the effort to retrieve the required items. However, after analyzing the two main strategies, the present research categories communication strategies into 12 strategies namely approximation, circumlocution, exemplification, comparison, word coinage, borrowing/code switching, foreignizing, repetition, non-verbal, avoidance, timestalling device, and appeal for assistance.

\section{LITERATURE REVIEW}

\section{Previous Related Studies}

Faerch and Kasper (1980) found that advanced English learners were likely to experience problems in their interlanguage in part simply because their communicative aspirations often increase with their developing interlanguage proficiency. However, these advanced English learners needed to use communication strategies in an unobvious way because they tended to establish their less clearly marked foreigner roles. Also, they tended to pay more attention to face-losing issue as well as the perceptions of embarrassment when communicating in English as a foreign language.

Paribakht (1985) reported a study, which he cooperated with 20 adult subjects, and conducted an empirical study at the University of Toronto in 1981. This study revealed: First, the typology of the strategies, which was developed, was based on the type of information included in the communication strategies. Second, the subjectes point of view was the basis for the identification of his or her communication strategies. Third, consideration in the identification of the subjects $^{\text {ee }}$ communication strategies was that very often a subjects ${ }^{\text {ee }}$ statement contained several communication strategies. 
Chen (1990) directed her experiment in Guangzhou of Mainland People's Republic of China, which was for discovering whether the language learners with different English proficiency applied communication strategies at the same level of frequency. Through training twelve English majors at a Foreign Language Institute, Chen (1990) revealed that "the high-proficiency learners were equipped with more knowledge of the target language and had relatively richer resources to draw upon in communication; therefore, they appealed less to communication strategies."

\section{Some Pertinent Ideas}

\section{Communication Strategy}

Since communication breakdowns can occur anytime among first language, second language and foreign language, the communication must be overcome through the use of communication strategies. There are some definitions have been presented by the experts. In Littlewood (1984), he said that communication strategies are the strategies used by the learners in coping with the situation and also to get the meaning across. The learners may find difficult in the conservation maybe because of the lack of vocabularies in their second language. Moreover, learners sometimes face the problem of communication while they are already engaged in speaking. Therefore, they have to find $n$ alternative way or another way of getting the meaning across. The problem of communication also happens in our native language. It may be similar to occasions ourselves and must either change our meaning outside the repertoire of language.

Another definition of communication strategies are introduced by Ellis (1997). According to Ellis, every learner who has tried to communicate in a second language will experience problems in saying what they want to say because of their inadequate knowledge. In order to overcome the problems in communication, learners will find some ways to make the conversation go on. Poulisse (1984) defined communication strategies as strategies which a language user employs in order to achieve his intended meaning on becoming aware of problems arising during the planning phase of an utterance due to his own linguistic shortcoming.

Communication Strategies is defined as a systematic technique employed by a speaker to express his or her meaning when faced with some difficulty (in Dornyei, 1995). What is meant by difficulty here meant by difficulty here is lack of basic grammar and vocabulary in the target language. Communication strategies help the learners to keep on using the language in communication with others. If they do not know certain words, they can use some types of Communication Strategies so that the conservation can still go on. EFL students use these strategies to compensate for the lack of vocabularies, grammatical knowledge, or ideas due to language anxiety, in this case communication apprehension. 


\section{Taxonomies of Communication Strategy}

a. Taronees Taxonomy (1977)

In his taxonomy, she classified the communication strategies in five parts

1) Avoidance consists of two kinds, namely topic avoidance and message abandonment.

2) Paraphrase consists of three kinds, namely approximation, word coinage, and circumlocution.

3) Conscious Transfer consists of two kinds, namely literal translation and language switch.

4) Appeal for assistance: asking for the correct termor structure.

5) Mime: Using non-verbal strategies in $\mathrm{p} \mathrm{la} \mathrm{c} \mathrm{e} \mathrm{of} \mathrm{a} \mathrm{meaning} \mathrm{structure}$

b. Bialystok"s Taxonomy (1983)

Bialystokes taxonomy is organized around the source of information that is the basis of the strategies. Accordingly, Bialystok"s taxonomy is structured into three categories as follows:

1) L1- based strategies has three kinds namely, language switch, foreign zing, and transliteration

2) L2-based strategies has three kinds namely, semantic contiguity, description and Word coinage.

3) Paralinguistic strategies have two kinds, namely gesture and mime.

c. Poulisse"s Taxonomy (1993)

Poulisse"s taxonomy is one of the most well known among those addressing the compensatory approach. It is based on Levelte"s (1989) psycholinguistic model of speech production, which draws a distinction between conceptual and linguistic levels of language production. The taxonomy results from a wide-ranging, empirical communication strategy research project, the so-called "Nijmegen Project". The taxonomy consists of the following three "strategy families":

1) Substitution plus Substitution strategies have six kinds, namely original analocical, conventional analogical, literal comparison, word transfer, subordinate and simple word transfer.

2) Substitution plus strategies only has one kind namely, morphological creativity which functions to make up an English word that is similar to the target item

3) Re conceptualization strategies consist of five kinds, namely componential analysis, function. Activity, place, and emotion.

4) Functional reduction strategies consist of two kinds, namely word abandonment and word avoidance.

d. Dornyei and Scottes Taxonomy (1977)

Dornyei and Scott (1997) classified communication strategies according to the manner of problem management, that is, how communication strategies contribute to resolving conflicts and achieving mutual understanding. They identified three basic categories, namely, direct, indirect and interactional strategies (Dornyei \& Scott, 1997)

1) Direct strategies: Providing an alternative, manageable and self-contained means ofgettingthemeaningacross, likecircumlocutioncompensatingforthelackof a word

2) Indirectstrategies:Strategieswhicharenotstrictlyproblem-solvingdevices, but facilitate the conveyance of meaning indirectly by creating the conditions for achieving mutual understanding

3) Interactional or modification device strategies: An approach wherebyt h e participants carry out a trouble-shooting exchange cooperatively

In short, this taxonomy views communication management as having two choices at each layer - to pursue or drop the message when problems occur and if the decision was 
to pursue it, there are two ways available : to use their own resources or to involve other interlocutors in an attempt to understand the message

\section{METHOD}

\section{Design and Samples}

This research employed qualitative research. This research used observation checklist and video recording in taking the data. The participants of this research are the English education students of academic year 2018/2019 of UNIMUDA Sorong. Those were chosen purposively based on the consideration of the richness of data on communication strategies in the classroomm. The subject was Teaching English as a Foreign Language (TEFL).

\section{Instrument and Procedure}

Two kinds of instruments-observation checklist and video camera were applied in this research. Observation checklist used in gathering the required data dealing with the communication strategies used by each participant during the teaching and learning process takes place.Video camera was used to shoot and to record the talk and body language during the teaching and learning process.

\section{Data Analysis}

The collected data from questionnaire has analyzed through several stages. The researcher analyzed the data based on Miles and Huberman (1994) data analysis. They are data reduction, data display and conclusion drawing and verification.

\section{RESULT AND DISUSSION}

\section{The Students' Communication Strategy Used}

In the context of English as a Foreign Language (EFL), it has been widely claimed by most Indonesian learners across different levels of education that speaking is a difficult skill to learn. Shumin (2002) stated that speaking a language is especially difficult for foreign language learners because effective oral communication requires the ability to use the language appropriately in social interactions. Shumin se statement may indicate that learners encounter problems in using the target language (TL) in oral communication if they do not have adequate communicative competence that underlies speaking proficiency. One of the way to practice the speaking is presentation activity.

Communication strategies have been an extremely important topic of discussion when it comes to second and foreign language learning, particularly in oral communication. The learners as speakers and as listeners may encounter various communication problems when they are limited competencies in the target 
language, and they may attempt to surmount the problems by employing some tricks or strategies to enhance the achievement of communication goals. In order to convey the messages and maintain them in a speaking activity until communication purposes are reached, the learners need to employ speaking strategies which are commonly referred to communication strategies. Based on the result above, we can conclude that the types of communication stratetgy which is used by the students in presentation consist of six types. They are apprximation, circumlocation, exemplification, word coinages, code switching and use of fillers.

„Approximation" was a strategy that the learner employed as an attempt to facilitate in conveying message to listeners in order to be easy understood by rewording their message. This strategy was used to face down the problem in lexical meaning transmission by using a TL word or structure which shared semantic features with the intended TL word instead. In this study, even though the alternative words that the learners used sound inappropriate, they seemed to successfully help the listener to catch the general meaning of what the speaker has said.Here, the researcher found an utterance of a lecturer using the approximation strategy;

\begin{tabular}{|l|}
\hline \multicolumn{1}{|c|}{ Utterances } \\
\hline or I am going to perform our masteries first the activities vocabulary here I will \\
present about how to teach listening effectively..
\end{tabular}

(Observation on December 28, 2018)

„Circumlocution" was a compensatory strategy that viewed as one of good solutions to solve the learners ${ }^{\text {ee }}$ limited TL knowledge. It deals with describing the characters or elements of the object or action instead of using the appropriate TL item or structure. This kind of CS used when the speaker described the characters or elements of the object or action as opposed to exert the appropriate TL word and structure. In other words, this strategy used by a speaker who does not know or is unable to recall a word but wants to express a concept. In place of using a circumlocution, the speaker delineated a brief sequence of words to express the same meaning.More detailed information concerning the categorization is depicted:

\begin{tabular}{|l|}
\hline \multicolumn{1}{|c|}{ Utterances } \\
\hline - Any other opinion or suggestion about Speaking? \\
- .......oke thank you. Speaking for me is like seperti people speak and \\
the person atau pembicara meng-understand what the pembicara bilang \\
begitu... \\
(Observation on November 15, 2018)
\end{tabular}

„Word coinage ${ }^{e e}$ was a strategy that created by speakers through creating a new word from selecting a TL term or term features that were known in their mind when conveying message to make the listeners comprehend of what have just uttered. It was used to overcome the difficulty in transmitting of the meaning of particular lexical in message by making efforts to make up a new word or 
expression form by combining the known TL items into morphology to engender the intended meaning.

\begin{tabular}{|l|}
\hline \multicolumn{1}{|c|}{ Utterances } \\
\hline $\begin{array}{l}\text { make it fluency because focus on the third here there is no new vocabulary here, } \\
\text { this is know ee unknown vocabulary } \\
\text { (Observation on December 11, 2018) }\end{array}$ \\
\hline
\end{tabular}

"Exemplification" serves into knowledge-based communication strategies by which the speaker conveys the concept by exploiting his/her world knowledge by forming examples, giving similes, and providing cultural characteristics. The speaker gives examples such as stories, people, occasions, and novels that reflected the meaning of the concept.When describing the object the speaker use common expressions of exemplification such as for example les, for instances, examples include, etc.

\begin{tabular}{|l|}
\hline Utterances \\
\hline for example: the next for introvert one can be eeh eeh one group with \\
introvert, another why because I read it \\
We as a teacher and then give the students the topic a for example but in this, in \\
this approach aa we like the students who choose the topic \\
(Observation on October 3, 2018)
\end{tabular}

In EFL speaking class in which English is used as the medium of communication among the learners, they may always switch TL into L1 or another language (code switching). The speakers sometimes substitute their stretches of utterances from single word up to complete alteration to their own words because they do not know the TL words when articulating their utterances. They exerted their own language to face down their TL lexical deficiencies and because of wanting, the communication sustains in keeping the conversation running properly. The speakers substituted their utterances to the L1 words because they did not know the TL words when articulating their utterances. They exerted their own language to face down lexical deficiencies of the TL and keep their communication running well in a properly manner. The three excerpts below represent the use of the strategy by Lecturer 1.

\section{Utterances}

yang disini yang di tiga ini bukan vocabulary baru tetapi vocabulary yang sudah ada, begitu to purpose vocabulary and here focus on...focus in structure when the student interest on one subject about they don't know the vocabulary (Observation on November 19, 2018) 
"Filler" is one part of the communication strategies which is defined as speaker uses gambits to fill pauses, to stall, and to gain time in order to keep the communication channel open and maintain discourse at times of difficulty. The reasons of employing the strategy were to gain time to think before starting or continuing the constructed sentences, to avoid silence which was not good to be done in front of students, to reduce awkwardness in talking, to approve the students ${ }^{\text {ee }}$ statement, and to give positive impact to students because of always listening positive reinforcement. The other presenters who were also observed did not use fillers in presenting the topic. the teaching and learning process in which they preferred being silent rather than used the strategy. The examples of the strategy can be seen in the excerpts in the table below:

\begin{tabular}{|l|}
\hline Utterances \\
\hline .... Ok, will be all student a couldn't how to make a classroom. .... How to a make a \\
discussion in this current in female.,,, Ok, next the answer. Ok, I will be there answer \\
the question. You say in this approach there over the special one...
\end{tabular}

(Observation on October 15, 2018)

\section{CONCLUSION AND SUGGESTIONS}

Finally, the researcher conluded that from the twelve features of communication strategies there are six features of communication strategies that the students used in doing presentation. They are approximation, cicumlocation, examplification, wod coinages, code switching and use of fillers. Approximation was used because the used strategy can attract more the students ${ }^{\text {ee }}$ attention. Circumlocation was used because the students wanted to make direct contact to the students in order to make the successful teaching and learning process. examplification was used because it can reflect the meaning of the concept. Word coinages because they might forget the appropriate words/term. Code switching was used because they felt more comfortable in case she combined between Bahasa Indonesia and the English language. Use of fillers was used because the strategy was very significant particularly second or foreign language speaker. The most frequently communication strategy that the students used is use of fillers.

Several suggestions are given for some elements including the further research in communication strategy. For future researchers, this study is limited on elaborating the types of CSs, it can be used as the starting point for the future researchers to explore other aspects of communication strategy of speaking. Furthermore, it is considered important to suggest those who want to conduct the study in this field. It is suggested that future researchers to explore more communication strategy by conducting different research designs, subjects, and settings; the effectiveness of communication strategy training,communication strategyused by EFL learners with native speaker of English either in a speaking class or in other contexts; communication strategy viewed from different sexes (gender),communication strategy viewed from different learning styles, and 
communication strategy viewed from different motivation; these are various fields of investigation.

\section{REFERENCES}

Bialystok,E. (1990).Communication Strategies: A Psychological Analysis of Second Language Use. Great Britain: Basil Blackwall.

Chen,S.Q.(1990).A Study of Communication Strategies in I nterlanguage Production by Chinese EFL learners. Language Learning, 40,155-187

Corder,S.P. (1983).Strategies of Communication. InC. Faerch \& G. Kasper(Eds.), Strategies in Interlanguage Communication(pp.15-19).NewYork:Longman.

Dornyei,Z., \& Scott,M.L.(1997).Review Article. Communication Strategies in a Second Language:Definitions and Taxonomies.LanguageLearning,47,173-210.

Ellis,R. (1997). Communication Strategies and the Evaluation of Communicative Performance. ELT Journal. 38 (1), 39-44.

Faerch,C.,\& Kasper, G. (1980).Processes and Strategies in Foreign Language Learning and Communication. Interlanguage Studies Bullein,5,47-118.

Littlewood, W. (1984). Foreign and Second Language Learning: Language Acquisition Research and Its Implication for the Classroom. Cambridge: Cambridge University Press.

Littlewood, W. (1991). Foreign and Second Language Learning (8th ed.). Cambridge: Cambridge University Press.

Miles, M. B. \& Huberman, A. M. (1994). Qualitative Data Analysis (2nd ed.). London: SAGE Publications Ltd.

Paribakht,T.(1982).The Relationship between the Use of Communication Strategies and Aspects of Target Language Proficiency: A study of Persian ESL Students. Unpublished doctoral dissertation, University of Toronto,Toronto.

Poulisse,N.(1993).A Theoretical Account of Lexical Communication Strategies. InR. Shcreuder \&B. Weltens (Eds.), The bilingual lexicon. Amsterdam: John Benjamins.157-189.

Shumin, K. (2002). Factors to Consider: Developing Adult EFL Students speaking Abilities. J. C. Richards, \& W. A. Renandya (Eds.). Methodology in language teaching (pp. 204-211).

Tarone, E. (1977). Conscious Communication Strategies in Interlanguage., in $\mathrm{H}$. DouglasB.,CarlosY.,and Ruth H.C.(Eds).TESOL.Washington D.C., 194- 203.

Tarone,E.(1983).Conscious Communication Strategies in Interlanguage:A progress report.TESOL,77,194-203. 